in conclusion, Mr. Editor, I beg to tell Mr. Edmonds, or any one else, that a young gentleman who has served an apprenticeship to a practitioner holding the double qualification, is, if he possesses a good character, and has made good use of his time, fit to be an assistant to any medical man requiring his services. I am one of the latter class; I have attended scores of labour cases, and without these I might have read all our obstetric authors' works in vain. In fact, you may read till you are blind, and be little the wiser; you must have actual practice.

Yorkshire, December, 1852 . I am, Sir, yours obediently, AN A SSISTANT.

\section{UNQUALIFIED SURGEONS TO EMIGRANT SHIPS.} To the Editor of The LaNCET.

Sin,-Your correspondent, "Mat," who has so ridiculously commented upon $m y$ letter respecting unqualified surgeons on board ship, is so void of any sense, that I should only be placing myself upon a level with him were $I$ to enter into the minutiæ of his letter.

Every sensible man would feel that "G. S. M.'s" remarks were ouly to the purpose. "G. S. M.", as long as he is a nember of a noble profession, will uphold the rights of it, and also that of the public. If "Mat" had one grain of sense, he would not have argued a point in which the voices of nearly the whole world would be against him. I would just allude to one or two of his sensible remarks. He adds-" And yet, cannot an nnqualified man attend to them as well as a qualified one?" My reply to this question is this. Any muff "may attend to them ;" but the question comes-Is he competent? I say no, he is not. No man who has not had the education to fit him for the medical profession, can with any degree of conscience attend to the wants of an ailing community. A man must have been educated expressly for his profession. He must know the mechanism of the human frame; he must know the uses, properties, and doses of medicines, \&c.; and he ought to know some theory. Again, with respect to the fifty guineas, which "G. S. M." had offered to him, with free passage. This was unsolicited, "G. S. M." not having contemplated going to Australia yet. Therefore "G. S. M." was not "disconcerted" upon that score. He was indignant that any advertisement should have been placed in a highly respectable paper like the Times, and coming from a respectable firm, offering a free passage with emolument to any person not possessing a diploma. If members of the medical profession do not uphold its rights, pray who are we to look to, to do so?

One word more in allusion to "Mat"s" remarks in speaking of unqualified assistants. I would ask him, Who takes the responsibility when an unqualified man is engaged by a qualified practitioner? Why, his employer, to be sure; and if a case goes badly, he has him at his right hand, to correct any egregions mistakes. Not so on board ship; the surgeon has ALL the responsibility, and if he falls into error in treating any case, who is to rectify it? Perhaps the captain or chief mate, but most likely death will terminate the scene. Now, where is this man's conscience? I say he can have none at all. I speak as I feel upon the subject. Without saying a word more, I would just refer "Mat" to the leading article of THE LANCET of December 18 th, and he will be convinced who is right. As to the remarks which he makes upon Mr. Edmonds's letter in conjunction with my own, I will leave that gentleman to give him what he so richly deserves.

$$
\text { I am, Sir, your obedient servant, }
$$

Wye, Dec. 1852 G. S. M., M.R.C.S.L.

\section{THE COLLEGE OF SURGEONS AND THE MEDICAI ASSOCIATION. \\ To the Editor of The Lancet.}

Sin,-There is a Siamese-Twin-ship existing between medicine and surgery, which is inseparable, and if disunited destroys both; one is absolutely necessary to assist and aid the other to effect that lofty function which is required for the finite exaltation of the medical profession; and therefore it is not unreasonable to expect that the College of Surgeons may at no distant period become an emulating body-throw off its fettered predilectionsand fasten the connecting link of surgery and medicine by an indissoluble chain-in examination.

Is it not whispered that there is a conjugal amour existing between the College of Surgeons and the College of Physicians, which may end in a speedy matrimonial alliance? Is there any cause or impediment why they should not be joined together? Let the profession declare it ; and if it be contemplated, let there be a speedy union, as the offspring would be welcomed and hailed as a legitimate race.

If the above prognosis, combined with the few predicting re- marks I made in THE LANCET on the 18th, be correct, does it not foreshadow a reason for the apathy and indisposition evinced by the College of Surgeons towards the Medical Association?" "they (the College of Surgeons), have not yet expressed their opinion on the Bill in any direct way?" again, "it has been whispered that the College is opposed to all medical reform-all future improvement."*

Their tactics one cannot but help thinking and hoping run deep in an ander-current in another direction. Such an enlightened body cannot evince inertia for progressive medical reform based upon improved princlples, when the great body of practitioners are clamorously contending for it! Their silence we must construe into consent;- - but silence too long maintained in this busy time of reformation becomes unsatisfactory and tedious; and many a stanch friend merges through it gradually into feelings of contempt; contempt engenders disgust; and disgust terminates in envy and open warfare.

I remain, Sir, your most obedient, humble servant

Cambridge-terrace, Hyde-park, Dec, 1852.

W. H. Bonham.

\section{UNQUALIFIED PRACTITIONERS AND ALLEGED FORGED DIPLOMAS.}

T'o the Editor of The LaNceT.

SIR,-As I consider it my duty to put the profession in pos. session of the following facts, will you be so kind as to give these letters a place in your widely-circulated journal?

A person styling himself Dr. 'Trull commenced practice here as a physician, in November, 1851. In the course of conversation with him, I satisfied myself that he was not what he proclaimed himself to be-namely, M.D. Aberdeen, 185l, ExtraLicentiate, Royal College of Physicians, 1851. I therefore addressed letters of inquiry to the Secretary of the Royal College of Physicians ; to Dr. Fyfe, Professor of Medicine, King's College, and to Dr. Macrobin, Professor of Medicine, Marischal College, Aberdeen; whose replies I subjoin, which, taken together, prove that Trull was not what he represented himself to be.

\section{[Copies.]}

Royal College of Physicians, Feb. 25, 1832.

My Dear SIR,-There is no such name as John Trull on the books of the College, neither has any person of that name obtained a diploma here in 1851 , or at any other time.

Ever, my dear Sir, yours truly,

Dr. Steavenson, Hastings. ROBERT L. RAWES.

King's College, Aberdeen, Feb. 28, 1852 .

SIR,-In reply to yours of the 25 th, I have to state that the name John Trull does not appear in the List of Graduates (M.D.) of this University for 1851 .

Dr. Steavenson, Hastings.

$$
\text { Yours, respectfully, }
$$

\section{ANDREW FYFE,}

Marischal College, Aberdeen, May 1, $182^{2}$

SrR,-No such person as John Trull, or any similar name, has ever graduated in this University,

Dr. Steavenson, Hastings.

I am, Sir, your obedient servant,

J. MACROBIN, M.D., Professor of Medicine.

On the receipt of the last letter, I sent copies of them all to Trull, who soon after left Hastings, promising not to use the diplomas again, believing that they were forged.

I find, however, that he is now residing at No. 1, Gloucester Cottages, Prior-park-road, Bath, and that he is known at the Post-office as Doctor' Trull.

Hastings, Dec. 1852 . I am, Sir, your obedient servant, J. Steavenson, Licentiate Royal College of Physicians.

\section{futerical $\$ 2$ efus.}

Apothecaries' Hall. - Names of gentlemen who passed their examination in the science and practice of medicine, and received certificates to practise, on

$$
\text { Thursalay, December } 30 t h \text {, } 1852 .
$$

Harris, William Henry, Hon. East India Company's Service.

Hawke, Charles John, Port Philip, Australia.

Willis, Simon Armstrong, Flonence Count, co. Fermanagh, Ireland. 